\title{
Quality of research as source and signal: revisiting the valorization process beyond substitution vs complementarity
}

\author{
Andrea Bonaccorsi ${ }^{1}$ D $\cdot$ Brigida Blasi $^{2} \cdot$ Carmela Anna Nappi $^{2} \cdot$ Sandra Romagnosi ${ }^{2}$
}

Accepted: 21 April 2021 / Published online: 21 May 2021

(c) The Author(s) 2021

\begin{abstract}
In recent years, the growing interest of universities in valorization of research activities (tipically through technology transfer-patenting and licensing-and academic entrepreneurship) has generated a debate on its impact on scientific knowledge production. There have been controversies on the potentially negative effect of university research valorization on public research, in terms of quality, long term vs short term orientation, and accessibility. The debate has been traditionally framed in terms of substitution vs complementarity between public research and valorization. In this paper we argue that the key to understand the relation between public research and valorization lies in the role of research funding, particularly: (a) competitive public research funding; (b) third party commercial funding. If the funding system (both public and private) takes the value of academic research as signal of quality, then high quality researchers are able to attract extra-funds beyond ordinary endowment. In turn, these additional funds can be used as a source to organize an effective and long-term division of labor in laboratories in order to support inventions and licensing (patents) and entrepreneurial activities (spin-off companies). In this case academic quality and commercialization are strong complement and positive feedback loops are generated. This interpretation on the role of funding is strongly supported by original data from the Italian Evaluation of Research Quality VQR 2011-2014 dataset. The paper is based on a unique and novel dataset, that integrates data on valorization of research activities at individual and institutional level on all the Italian universities and microdata on research quality on 32,616 researchers in STEM disciplines.
\end{abstract}

Keywords Third mission $\cdot$ Research quality $\cdot$ Academic patenting $\cdot$ Academic entrepreneurship - Third party funding

A preliminary version of the paper has been presented at the Helsinki Conference (Helsinki, 2018), the ISSI Conference (Rome, 2-5 September, 2019) and is included in a report by ANVUR and in related papers (Blasi et al. 2018; 2019a, 2019b). We thank Cinzia Daraio, Joaquin M. Azagra-Caro and Fredérique Sachwald for constructive comments. We also thank Francesco Lissoni (Université de Bourdeaux and Bocconi University) and Riccardo Fini (University of Bologna) for the institutional collaboration with ANVUR in the construction of the patent database and the spin-off database, respectively.

Andrea Bonaccorsi

andrea.bonaccorsi@unipi.it; a.bonaccorsi@gmail.com

Extended author information available on the last page of the article 
JEL classification $\mathrm{I} 23 \cdot \mathrm{O} 31 \cdot \mathrm{O} 32$

\section{Introduction}

In the last few decades universities have been subjected to strong pressure for change, triggering a discussion on the nature and missions of academic institutions. The valorization of research seems a largely accepted component of university mission.

This involves activities such as patenting of academic research (Nelson, 2004; Stiglitz \& Wallsten, 1999; Lissoni et al., 2008; Lawson, 2013; Link \& van Hesselt, 2019), patent licensing (Agrawal \& Henderson, 2002; Jensen \& Thursby, 2001; Sine et al., 2003; Thursby \& Thursby, 2002; Thursby et al., 2001), technology transfer (Agrawal, 2001; Barletta et al., 2017; Bozeman et al., 2015; Colyvas et al., 2002; Friedman \& Silberman, 2003; Mowery et al., 2004), academic entrepreneurship and the creation of spin-off companies (Rothaermel et al., 2007; Shane, 2004; Toole \& Czarnitzki, 2010). In order to realize these activities universities have created, or supported, dedicated facilities and organizations such as Industrial Liaison Offices (ILOs), Technology Transfer Offices (TTOs), and science and technology parks (Siegel, Waldman, et al., 2003). These activities are usually labelled as valorization of research, and more specifically, on the economic side, commercialization of research. As a matter of fact, the patenting of inventions from academic research or the creation of university spin-off companies have the final goal of commercializing university research. Yet it is not taken for granted that this goal is fully achieved (e.g. patents might not be licensed) since the process may fail or being interrupted before reaching the market (e.g. a spin-off may be liquidated). In all these activities, within the scope of the economic valorization of research, universities learn to interact with non-academic actors, mainly profit-oriented companies (Slaughter \& Leslie, 1997).

While the importance of valorization of research is largely recognized, a large debate is still ongoing on its impact on the other traditional university's missions, especially on research.

We contribute to the literature in three ways. First, we exploit the relation between research quality and valorization through data at different level, i.e. at the researcher individual level and at university level, covering a very large dataset and taking into account the variability of the phenomena under investigation. We exploit, for the first time, data from a national, official assessment exercise covering all the universities in a large European country and, within universities, all researchers in STEM disciplines. The data describe in great detail several dimensions of research valorization and relate them to indicators of research quality. With this aim, we have created a unique and novel dataset. This effort of data integration for a large country is unique, to the best of our knowledge.

On the basis of the dataset we develop two models.

(i) An individual-level model, in which the dependent variable is the count of patents invented by individual researchers in STEM disciplines, or academic patents (Inventive model)

(ii) Two university-level models, in which the dependent variables are the count of patents invented by academic researchers in STEM disciplines and owned by universities, or university patents, and the count of spinoff companies, respectively. 
By examining in parallel individual and institutional variables we are able to capture the valorization process in greater detail.

Second, we examine in an integrated way several channels of knowledge transfer and valorization, building up a more complex picture of the valorization of research. In particular, we shed light on the crucial role of third party funding on the sign and magnitude of the relation between research quality and research valorization. These findings have strong theoretical implications.

Third, we are able to control for a large number of contextual variables that have a clear relation with the theoretical debate on the impact of valorization on research quality.

Data come from the second round of the Italian national assessment exercise Evaluation of Research Quality (VQR, Valutazione della Qualità della Ricerca) 2011-2014 that has been carried out by the Italian Agency of Evaluation of Universities and Research Institutes (ANVUR) in 2016-2017. In this second round VQR 2011-2014, the evaluation of valorization activities has been introduced on a full scale, under a broader umbrella called third mission. There are clear limitations to this work. The most important one is that we cannot establish causality relations, given obvious problems of endogeneity in the relation between research quality and valorization. Due to the cross-sectional nature of data and the presence of discontinuities in the regulatory framework, most part of the counterfactual techniques cannot be used. We therefore frame our discussion in correlational terms. Another limitation, that may be addressed in a future study, is the lack of data on teaching activities. These data will be integrated in the near future. With these caveats in mind research questions and modeling strategy are hereby articulated.

\section{State of the art and development of hypotheses}

\subsection{Academic quality of research and economic valorization}

The issue of economic valorization of research has attracted lot of attention in the literature, from two perspectives. The first perspective was raised shortly after the legislative changes in the United States in the ' 80 s that promoted the patenting and commercialization of research funded by public sources. Here the perspective taken (in the tradition of Merton, 1968; Mitroff, 1974; Mulkay, 1976; Dasgupta \& David, 1994) is the one of researchers and of public interest: does the pursuing of a new mission by universities, in particular the valorization of research, add or subtract from the mission of producing high quality research? Is it good or evil for universities (Behrens \& Gray, 2001; Bozeman et al., 2016; Calderini et al., 2007; Carayol, 2003, 2007; Crespi et al., 2011; Gulbrandsen \& Smeby, 2005; Hicks \& Hamilton, 1999; Murray \& Stern, 2007)?

More recently, perhaps after the former stream of research has undergone diminishing returns, the perspective has been reversed. By assuming the perspective of the market some authors started to ask: are universities able to extract economic value from their research, or rather they fail in this mission?

Let us shortly review these streams of literature and discuss why the case of Italy, analysed in this paper, is interesting from the point of view of the advancement of knowledge.

The first set of questions has been since long time conceptualized within the framework, familiar to economists, of substitution vs complementarity (Perkmann et al., 2013; Van Looy et al., 2006). According to the substitution thesis, engaging into economic valorization of research will harm public research for reasons of efficiency, accessibility, and ethos. 
The efficiency argument was that researchers have a (relatively) fixed time budget, so that engaging into patenting or entrepreneurship would divert from academic research. In addition, doing research with a view on economic valorization implies re-orienting research agendas, from long term uncertain but fundamental results to short term incremental results. The accessibility argument stressed the perverse effect of intellectual property and/ or industrial secrecy on the attitude of researchers to publish results. The ethos argument implied that public researchers would be contaminated by the profit-oriented motivation of firms.

On the opposite side, the complementary perspective stressed that in frontier research, particularly in the so called Pasteur-quadrant disciplines or Transfer sciences, there is no efficiency problem, since working on applications and market valorization will open new and academically interesting research questions (Blume, 1990; Calcagnini et al., 2016; Stokes, 1997). The concerns about openness vs commercial appropriability can be managed within a sophisticated legal and contractual framework, making universities able to manage ambidexterity (Ambos et al., 2008; Chang et al., 2016; Fini \& Toschi, 2016) and pursue both publishing and patenting (Breschi et al., 2007; Owen-Smith \& Powell, 2003). With respect to the ethos of research, a severe discipline of conflict of interest, particularly in the medical fields, have mitigated the problems.

Summing up, our view is that this debate has led to a clear verdict in support of the complementary view. An overwhelming amount of evidence supports the view that the net balance is positive, that is, quality of research is not damaged, but rather enhanced, by valorization activities.

More controversial, in our view, is the recent stream of studies that put the problem the other way round: are universities able to generate the full economic value that they potentially have? If not, why?

In a fascinating paper Marx and Hsu (2021) have compared the inventions generated by universities with a control sample in which the same (or very similar) inventions have been obtained by commercial firms in the same period. Universities try to extract economic value from spinoff companies that go to the market, either by taking a share of equity or by charging licensing fees on intellectual property. The authors show that commercial firms are able to generate many times the economic value than universities for the same invention. Universities clearly lack the complementary assets needed to generate commercial success. In this sense good quality research is necessary but dramatically not sufficient for valorization.

In a somewhat related perspective, some authors have recently raised the argument that economic valorization does not need excellent research, but rather more ordinary activities of knowledge transfer, technical services, consultancies, with some important but occasional involvement of new research. In medium and low-tech industries the most important contribution played by universities is not the production of top quality research, but rather the education of students with a practical orientation and the engagement into trouble-shooting and problem solving activities of firms, which do not require high levels of research creativity (Barra et al., 2019; Freitas et al., 2013; Laursen \& Salter, 2004, 2006; Laursen et al., 2011; Maietta, 2015). Consistent with this theoretical background, Bekkers and Freitas (2008) found that mechanical and civil engineering firms make use of university cooperation not necessarily of top quality, while Abramovsky et al. (2007), found that pharmaceutical, chemistry and materials science R\&D tends to be located close to star departments in UK, while machinery and communication equipment R\&D is colocated with lower-quality rated research departments. According to this view, good quality research is not strictly necessary for valorization. 
While this debate is crucial for the future of universities in all countries, it is important to examine why the case of Italy may add original insights. We see three reasons.

First, Italy is a unitary higher education system in which all tertiary education and research functions are carried out by one type of institution, that is, the $\mathrm{PhD}$-granting, public, generalist university. ${ }^{1}$ Non-university institutions such as colleges or bachelor-only schools are confined to a few disciplines in Art, Music and Drama. Our data cover only universities. It is important to remark that in the Italian context, for historical and institutional reasons, there is no formal stratification of universities according to their research intensity. All universities are equally engaged into research, although their average research quality is different. Empirically, differences across universities in research quality have lower magnitude than within-university differences (Bonaccorsi \& Cicero, 2015). For these reasons it would be difficult to replicate the discrimination between High Research Intensity (HRI) and Low Research Intensity (LRI) universities used, for example, by HewittDundas (2012) for the UK case. This means that all university researchers, particularly in STEM disciplines, are implicitly held responsible not only for their research and teaching but also for technology transfer and research valorization. In the absence of universities, no other specialized institution would do the job on a systematic basis.

Second, Italian universities are notoriously understaffed and underfunded. All comparative analyses show that Italy has a lower number of researchers in proportion to the population and a much lower higher education expenditure per student. These two features point to an exacerbation of the possible trade-off between research quality and research valorization. It is not an exaggeration to state that Italian researchers and professors are asked to contribute to research valorization while they are also committed to teach to a large (on average) number of undergraduate students and to fight to acquire funds out of a meagre national research budget. At the same time academic researchers make their career mainly on the basis of scientific publications, so that the incentives to allocate time to non-publication activities are weak, as discussed by a large recent literature (Hmieleski \& Powell, 2018; Ho et al., 2016; Loi \& Di Guardo, 2015; Meek \& Wood, 2016; Tartari \& Breschi, 2012; Watermeyer, 2015).

Finally, the Italian economy suffers from a prolonged dualism, with Southern regions well below the European level of GDP per capita and the level of business R\&D. It is safe to say that universities find it more difficult to interact with industry in Southern regions.

All these features of the institutional system may put into question the overall positive relation between research quality and valorization which is largely confirmed by the literature. It might well be that, due to heavy constraints in terms of staff and funding, Italian researchers must choose between publishing and patenting, or between publishing and creating spinoff companies. They cannot do the two things together. If they engage actively into valorization, their research quality will suffer significantly and their career prospects may become weaker. For these reasons it is interesting to re-open the empirical issue of the relation between academic quality of research and valorization activities in a context in which there is strong tension between the two.

\footnotetext{
${ }^{1}$ This lack of institutional differentiation is also found in applied research and technology transfer. The diffusion of non-university intermediaries for technology transfer is scattered and their operations are relatively inefficient. No institutional country-wide mission to non-university organizations (such as Fraunhofer) is in place.
} 


\subsection{Role of funding}

Most existing studies examine the relation between the absolute and relative level of funding and the volume and quality of scientific production. At an aggregate level a positive relation between the volume of research funding and the volume of scientific production is largely confirmed (McAllister \& Wagner, 1981; Boyack \& Borner, 2003; Carayol \& Matt, 2004; Jacob \& Lefgren, 2011; Bolli \& Somogyi, 2011; Rosenbloom et al., 2015). This relation is obviously affected by endogeneity. Using data at the level of individual researchers, however, Ebadi and Schiffareuva $(2015,2016)$ and Mongeon et al. (2016) address the endogeneity problem associated to funding and examine the marginal effects of increase in public funding. Their results support the notion that increased funding is associated not only to increased volume of production, but also to increased productivity. These findings confirm those by Beaudry and Allaoui (2012) and Fedderke and Goldschmidt (2015).

The literature on valorization has, in general, payed little attention to the relation with research funding and, in particular, on the different impact of various sources of funding (Goldfarb, 2008; Rosli \& Rossi, 2016). We propose that this relation is instead crucial. The argument is the following. Researchers receive funding for their research through three main sources: block funding at university level, competitive public research funding and third party funding. Block funding is allocated by the government to universities and subsequently allocated to researchers per capita, or possibly with little variability across individual researchers. It is considered to be the minimum funding needed to pursue research. We suppose that this funding is not sufficient to engage into valorization. This requires an extra effort e.g. the paper work related to the drafting of the text of patents, the discussion with lawyers and consultants, the creation of business plans for spinoff companies, the lengthy negotiations with business angels, incubators' management and VCs.

According to this argument, researchers can do valorization only if they get additional resources. They procure the additional funding in two main ways: by competing in national and international calls, and by receiving money from third parties, in particular from companies through contract research (Hornbostel, 2001; Bruno \& Orsenigo, 2003; Laudel, 2005; Larivière et al., 2010; Nag et al., 2013; Muscio \& Nardone, 2012).

However, this creates in turn additional burden for the management of project applications and implementation. Only once the flow of additional resources becomes steady and predictable, senior researchers may hire junior researchers to be assigned to contract research tasks and dedicated staff for the project management. Junior researchers acquire advanced skills to be employed in their future career. Within a larger team, junior researchers may also choose to create spin-off companies instead of pursuing an academic career. These spin-off companies will maintain, however, close linkages with the academic background (Blasi \& Romagnosi, 2012).

Over time, publishing articles, on the one hand, and drafting patents or creating spinoff companies, become joint products of the same high level cognitive production process. Additional funding, in other words, permits a better division of labor within laboratories. It is this division of labor that ensures scientific quality of research and valorization to go hand in hand. This dynamic and virtuous circle, however, requires institutional support at university level.

If this hypothesis is correct, then we expect that in our dataset the indicators of funding will enter the models of explanation of the variability in the valorization performances. 


\subsection{Context effects}

In this section we review control variables, whose role is to be taken into account, to the largest possible extent, for the heterogeneity in the way in which academic research leads to valorization. We distinguish disciplinary, regional and institutional effects, including in the latter the role played by the presence of Technology Transfer Offices (TTOs).

\subsubsection{Disciplinary effects}

The existence of disciplinary differences has been recently emphasized in empirical research on valorization (Sánchez-Barrioluengo, 2004). The effect of the disciplinary specialization of the institutions is relevant and engineers are recognized to be more active in industrial partnerships (Freel et al., 2019), while life scientists in commercialization of results since research in that field has a direct impact on technology development (Zucker \& Darby, 1996; OECD, 2013; Laursen \& Salter, 2004; Callaert et al., 2006). In the Italian context, Calderini et al. (2009) have examined the large differences within STEM disciplines in academic patenting and Bonaccorsi et al. $(2013,2014)$ have found that the impact of scientific outputs on the creation of new firms located close to universities is stronger in Engineering and Medicine, while it is negligible in Social Sciences and Humanities.

\subsubsection{Regional context}

The way in which universities interact with companies and valorise their research results is inevitably influenced by the regional context in which they are located (Bekkers \& Freitas, 2008; Freitas et al., 2013; Hill, 2006; Landry et al., 2010; Schartinger et al., 2002). This argument is supported by the recent reconsideration of the impact of universities on regional growth (Lawton-Smith \& Bagchi-Sen, 2012; Drucker, 2016; Brown, 2016; Bonaccorsi, 2016; Peer \& Penker, 2016; Teixeira \& Queirós, 2016).

In fact, the ability of companies to absorb external knowledge (for example, produced by universities) is a positive function of the internal, in-house investment into formalized R\&D. Only large firms are capable to scan the academic landscape at a global level and select the best universities in terms of visibility and prestige (Fontana et al., 2006; Link \& Scott, 2005; O'Shea et al., 2005; Powers \& McDouglas, 2005; Schartinger et al., 2002). Instead, SMEs are likely to look for a more targeted and applied know-how, and are more interested in geographical proximity and universities' capacity to support the whole innovation process and train high skilled workers (Fritsch \& Franke, 2004; Hong \& Su, 2013).

Given the stickiness of the industry specialization of territories, this selectivity effect takes a clear spatial structure. There is also preliminary evidence of a more general impact in the reverse direction, i.e. the impact of regional macroeconomic context on universities. Wolszack-Derlak (2017) shows that GDP per capita at regional level has an impact on the overall efficiency of universities in 10 European countries and the US, while Degl'Innocenti et al. (2019) find a similar effect on efficiency in generating income for the UK.

This issue is particularly prominent in the Italian context, given the divide between Northern and Central regions, and Southern and Insular regions. In catching up regions, in fact, the sectorial pattern of specialization is usually focused on traditional sectors, with a very low investment into $R \& D$. 


\subsubsection{University governance, specialization and type}

Universities differ along several dimensions (Daraio et al., 2011) and these differences are also reflected in different forms of strategy and organization of the knowledge valorization process (Schoen, 2014).

Within the Italian university sector we find three main characterizations:

(i) Governance: state vs non-state universities

(ii) Specialization: generalist vs specialist institutions

(iii) Type: universities vs graduate-only institutions

According to governance, a distinction between state and non-state universities is clearly established by the regulatory framework. Non-state universities are accredited and receive public funds for research, but do not receive funds for teaching.

According to the type, the legislation distinguishes between universities and a small number of institutions, called "Scuole Superiori di Studi Avanzati/Schools for Advanced Studies", which are dedicated to graduate studies and to the education of small classes of excellent undergraduate students, following the model of École Normale supérieure in France. There are also three Polytechnics (Milan, Turin and Bari) that are public technical universities which follow, differently from most other universities, a selective policy of admission of students. In our dataset, graduate-only schools and Polytechnics are treated together for their specific nature.

In principle, non-state universities may have a stronger incentive to produce commercially valuable outputs. In practice, however, the reverse is more likely. In the Italian context, in fact, non-state universities are concentrated in the fields of Business and Law (Bocconi, LUISS, LIUC) and Medicine (San Raffaele, Humanitas). The largest non-state university (Cattolica University) is mostly active in SSH, Medicine and Agriculture, while is clearly absent in basic science and Engineering. In the medical field, non-state universities are mostly active in clinical research. Summing up, the disciplinary background that characterizes Italian non state universities is not particularly favourable to the production of patents and spin-off companies.

Following the literature (Bonaccorsi \& Daraio, 2007) we distinguish generalist and specialist universities. Generalist universities might enjoy better conditions for valorization. Interaction between different scientific fields might be a favourable background condition, while the combination between STEM and inputs from social sciences (in particular, business and management schools) might also contribute to the creation of spin-off companies. In a study of orientation of Technology Transfer Offices (TTOs) in several European countries, Giuri et al. (2019) find that generalist universities are more oriented towards collaboration and support to local economic development in the form of spin-off companies and incubators. This is due to the broader disciplinary spectrum, which also includes SSH (Olmos-Peñuela et al., 2014), and the orientation of TTO staff to support more general collaborations (Munari et al., 2016).

Finally, also graduate-only schools and Polytechnics might enjoy better conditions for research valorisation. Having a lower teaching load, they might manage the trade-off between academic research and valorization in a more effective way. 


\subsubsection{Technology Transfer Office}

The role of the internal organization of universities for the design and implementation of valorization has been repeatedly examined (Chapple et al., 2005; Hülsbeck et al., 2013; Siegel Veugelers et al., 2007; Siegel, Waldman, et al., 2003). Fini et al. (2011) analyze the extent to which University-Level Support Mechanisms (ULSMs, such as Technology Transfer Offices and dedicated administrative staff) and Local-Context Support Mechanisms (LCSMs, such as incubators, technology parks, or specialized intermediaries) complement or substitute each other in fostering the creation of academic spin-offs.

The magnitude of the impact of TTOs on the effectiveness and efficiency of the knowledge transfer process is a matter of debate (Bozeman et al., 2015). Hewitt-Dundas (2012) and Sánchez-Barrioluengo and Benneworth (2019) find that the impact for UK universities is positive but small, while the strategic orientation of universities is more important. On the other hand, Fini et al. (2018) show that the tension between research quality and industrial impact are mitigated through the creation of a dedicated professional layer of agents. What is important is the fit between institutional goals and strategies and the organization of TTOs in terms of resources and skills, including tacit ones (Lockett et al., 2003; Schoen et al., 2014; Link \& van Hesselt, 2019).

\section{Data description}

The paper is based on the integration of two datasets. The first dataset (TM DB) was created from the procedure of third mission monitoring, started in 2015 and replicated annually (Annual Third Mission Form, or SUA-TM). Universities were asked to report detailed data on their third mission activities and outputs. Among them, a section on the valorization of research was included, covering patenting, creation of spin-off companies, and third party and contract research. Some of the variables are collected at university level, some of them are collected also at individual level. The period covered by this dataset is the same as the period of the second dataset, i.e. the years related to the second round of the research assessment exercise VQR 2011-2014.

The second dataset (VQR DB) includes individual-level data on the quality of research drawn from VQR 2011-2014. This dataset was used to build up the independent variables at individual level and also their aggregation at the institutional level. Control variables at university level are derived by the affiliation of the outputs' authors inserted at the submission by universities.

In this dataset a selection has been made to include only academic staff in STEM disciplines supposed to be more proactive in research valorization. The bordering has been made through SSD, a relatively narrow discipline-based code ("Settore Scientifico Disciplinare, SSD"). In the Italian administrative context, all academic staff are classified according to SSD and all SSDs are grouped in 14 broad scientific areas (Area CUN- National University Council Areas). STEM disciplines cover the areas corresponding to Mathematics and Computer science, Physics, Chemistry, Earth science, Biology, Medicine, Agriculture and Veterinary science, Civil engineering, Industrial and information engineering.

As already stated, we develop two types of models: an individual-level model, in which the dependent variable is the count of patents invented by individual researchers in STEM disciplines, namely academic patents (Academic invention model); and two university-level models, in which the dependent variables are the count of patents invented by academic 
researchers in STEM disciplines and owned by universities, namely university patents, and the count of spinoff companies, respectively (Institution valorization models).

In this section, we describe the variables and the data merge procedure. In the modeling strategy we relate the variability of dependent variables representing the valorization process (patents and spinoff companies) on the basis of independent variables (research quality and research funding), controlling for several disciplinary, regional and institutional factors.

Here we represent the valorization using only two simple variables in count (number of patents, number of spinoff companies). It must be recognized that a full picture should have included additional data on the final outcome of valorization, such as licensing revenues, or the turnover or employment of spinoff companies. ANVUR recognized this issue and asked universities to compile detailed data on these variables. It turned to be an exceedingly difficult and burdening process and there were many missing data, particularly for spinoff companies. One reason was that universities do not necessarily have a share in the equity of companies and do not always have direct access to the balance sheets: in many cases they rely on the willingness of spinoff companies to share financial or employment information. Another reason was that the procedure, during VQR 2011-2014, was not mandatory: it was clearly stated that the evaluation of third mission would not have an impact on university funding, differently from the evaluation of research. There are good reasons to believe that the data collection will definitely improve under the third round of 2015-2019 VQR, currently in place, in which the evaluation of the third mission gained central prominence.

In the following section, we describe the parts that compose the dataset on third mission (TM DB).

\subsection{Patents}

Patent data are taken from the European Patent Office (Worldwide Patent Statistical database) and refer to applications published in the period 2011-2014. By patent we mean the patent family, a collection of patent applications covering the same or similar technical content. The applications in a family are related to each other through priority claims, thus the family boundaries are provided by common references or are linked to a priority document, identifiable with the first application filed in chronological order.

Only invention patents published in offices that produce a search report have been included, and specifically in the European Patent Office (EPO), the Patent Cooperation Treaty (PCT), the US Patent \& Trademark Office (USPTO) and the Italian Patent and Trademark Office (UIBM). The selection of the offices was made to introduce a quality criterion on patents.

The data refer to academic patents, i.e. patents signed by at least one professor-inventor regardless of their ownership. These include university patents, i.e. patents owned or coowned by universities. Academic patents are an indicator of the individual inventive capacity and creativity of academic staff. University patents are a subset of academic patents, for 
which university offices have identified an interest and paid the administrative fees (Lissoni et al., 2012).

All professors, researchers, research fellows, $\mathrm{PhD}$ students and doctors of the university who are active on 31/12/2014 are considered as inventors. ANVUR has created an experimental semi-automated procedure ${ }^{2}$ in which the names and surnames of all academic staff have been cross-checked with the list of inventors of EPO, USPTO, PCT, and UIBM patents. This has created a first list of academic inventors that has been subsequently checked, validated and integrated ${ }^{3}$ by universities'staff in the VQR submission phase. If an inventor moved to another affiliation after the year of application, the patent was considered part of academic patents of the former institution.

Further information on university patents regarding cash receipts registered per year, from license, sale and option, have been collected during the assessment procedure. As already stated, all data refer to the VQR evaluation period (2011-2014).

In this paper we use only a measure of patent count, given that data on licensing are incomplete. A systematic effort is currently in place to obtain fully reliable data from universities on their income from licensing, an issue for which there have been claims of privacy restrictions.

\subsection{Spin-off companies}

The definition of spin-off companies was already established in the first round of the research assessment exercise VQR 2004-2010, as follows:

(a) s spin-off company is based on the research results produced by the university and regular research collaboration relationships have been maintained with it.

(b) the participation in the capital by universities or the presence of researchers in the company's governing bodies may occur but it is not strictly required.

(c) a formal and documented accreditation of the spin-off status by the university is required.

Spin-off data have been collected at the university level in relation to companies active and accredited by the university in at least one year in the VQR period. Since data on revenues of spin-off companies are characterized by a large number of missing values, only spin-offs that reported revenues in at least one year in the reference period have been included in the analysis. Data on firms have been collected from Chamber of Commerce database (firms created in the calendar year) and have been integrated and validated by universities in the submission phase. ${ }^{4}$ Data refer to 2011, 2012, 2013 and 2014 separately.

\subsection{Research quality}

In VQR 2011-2014, academics were asked to submit two research outputs published in the years 2011-2014 and quality of research outputs was assessed using an informed peer

\footnotetext{
2 The construction of the patent database was made possible thanks to the collaboration with Bocconi University (project leader prof. Francesco Lissoni).

3 The institutions had also the possibility to manually insert patents which did not result from the semiautomated procedure.

4 The construction of the database from official Chamber of Commerce data was made possible thanks to the collaboration with the University of Bologna (project leader prof. Riccardo Fini).
} 
review methodology with bibliometric indicators (see for details Anfossi et al., 2016; Bonaccorsi, 2020a, 2020b).

For each academic inventor we computed the mean of the two submitted outputs'scores and normalized it by scientific area's averages to take into account differences into evaluation parameters among the areas. ${ }^{5}$

These data have been then aggregated at university level using normalized and standardized indicators.

Only STEM fields scores were considered, since those fields are the most active in producing patents, spin-offs and third party funding. Therefore, on the basis of ANVUR data, we use:

(a) two university indicators normalized by scientific area (from now on $R$ Area) and by disciplinary Sector (from now on $R S S D$ ) weighted for the quota of outputs in the area / SSD for each university. We define: $v_{j, k}$ as the sum of the scores obtained from outputs in area $j$ (or SSD $j$ ) in the university $k ; n_{j, k}$ the number of research outputs of area $j$ (or SSD $j$ ) in the university $k ; V_{j}$ and $N_{j}$ respectively the total scores and the number of outputs in area $j$ (or SSD $j$ ) at national level. Hence we define a normalized indicator at university and area levels that compares university mean score in a specific area with national mean score in that specific area: $R_{j . k}=\frac{\frac{v_{j, k}}{n_{j, k}}}{V_{j} / N_{j}}$. By summing up all $R_{j, k}$ indicators in each university with a weight equal to the share of outputs in area $j$ (or $\operatorname{SSD} j$ ) on the total university production in terms of number of outputs $\left(N P_{k}\right)$, we obtain a single university indicator that aggregate the performances in all the areas (or SSDs):

$$
R_{k}=\sum_{j=1}^{J} R_{j, k} * \frac{N P_{j, k}}{N P_{k}}
$$

(b) a standardized indicator (ISA) at university and Scientific Sector levels obtained by summing up all the standardized scores $\left(V S_{i, k, s}\right)$ computed with respect to the mean and standard deviation for each SSD at national level: $V S_{i, k, s}=\frac{V P_{i, k, s}\left\langle\left\langle V P_{s}\right\rangle\right.}{\sigma_{s}}$. We define Standardized University Score $\left(V S_{k}\right)$ the normalized sum of all standardized scores in the university: $V S_{k}=\frac{\sum_{s=1}^{S} V P_{i, k, s}}{\sqrt{N P_{k}}}$. By using the normal cumulative function for the standardized university score, we can know the position of the university $k$ in the national distribution of universities with the same staff composition in terms of field specificity. This value multiplied by 100 represents the percentile in which the university stands and indicates the probability that a University $k$ compared with an ideal set of universities formed by the same number of staff members of university $k$ specialized in the same SSDs, but chosen randomly, obtain a lower evaluation than the one actually obtained.

$$
P_{\text {inf }}=\frac{1}{\sqrt{2 \pi}} \int_{-\infty}^{V S_{d}} \mathrm{e}^{-\frac{x^{2}}{2} d x}
$$

\footnotetext{
5 We also run robustness check using research quality scores standardized (standardization accounts for different means but also for different variances among scientific areas) and results are consistent.
} 


\subsection{Research funding}

Data on funding are derived from universities' balance sheets, available in a standardized form only for state universities. ${ }^{6}$

We distinguish between:

(a) research funding

(b) third party funding

Research funding (in log per capita) is the sum of block funding and competitive funding. Given that block funding for research is spread thinly among all researchers, the variability in this variable is almost entirely due to the ability to procure competitive funding in national and international calls.

This variable has large variability, since the minimum value (in $\log$ ) is 5.8226 and the maximum is 12.742 (see Table 1 for descriptive analysis).

Looking at the distribution, it seems that there are universities, at the bottom and top deciles of the distribution, in which researchers work with extremely different conditions of funding.

Third party revenues is the sum of:

- commercial activity revenues (including research and teaching activities carried out on behalf of third parties and other revenues deriving from commercial activities);

- income from business (private and public enterprises);

- income from institutional relations

Data are the sum of the third party funding of the university (i.e. registered at central level) and of its departments ${ }^{7}$ in the period 2011-2014 (annual average).

\begin{tabular}{llll}
\hline & Total & Mean (by universitites) & $\%$ \\
\hline Third party funding in the period 2011-2014 & 4.300 .963 .420 & 64.193 .483 .90 & 100 \\
Commercial activities & 1.447 .062 .491 & 21.597 .947 .60 & 33.6 \\
From commissioned research & 943.664 .076 .60 & 14.084 .538 .50 & 21.9 \\
From teaching activities, seminars and conferences & 50.872 .434 .05 & 759.290 .10 & 1.2 \\
From tariff services & 205.030 .693 .30 & 3.060 .159 .60 & 4.8 \\
From other commercial activities & 247.495 .287 .50 & 3.693 .959 .50 & 5.8 \\
Income from business (private and public enterprises) & 768.400 .480 .10 & 11.468 .663 .90 & 17.9 \\
Income from institutional relations & 2.085 .500 .448 & 31.126 .872 .36 & 48.5 \\
Institutional relations excluding municipalities, prov- & 415.547 .117 & 6.202 .196 & 9 \\
$\quad$ inces, regions and other Public Administrations & & & \\
\hline
\end{tabular}

Source: ANVUR Annual Biennal Report 2018

\footnotetext{
${ }^{6}$ Non-state and online Universities data have been eliminated from the dataset because they use different financial reporting models).

7 The third-party funding for the 2011-2012 period relates only to the third-party of the university (and not to its departments). For the period 2013-2014, the third party is the sum of the third party funding of the university and its departments.
} 


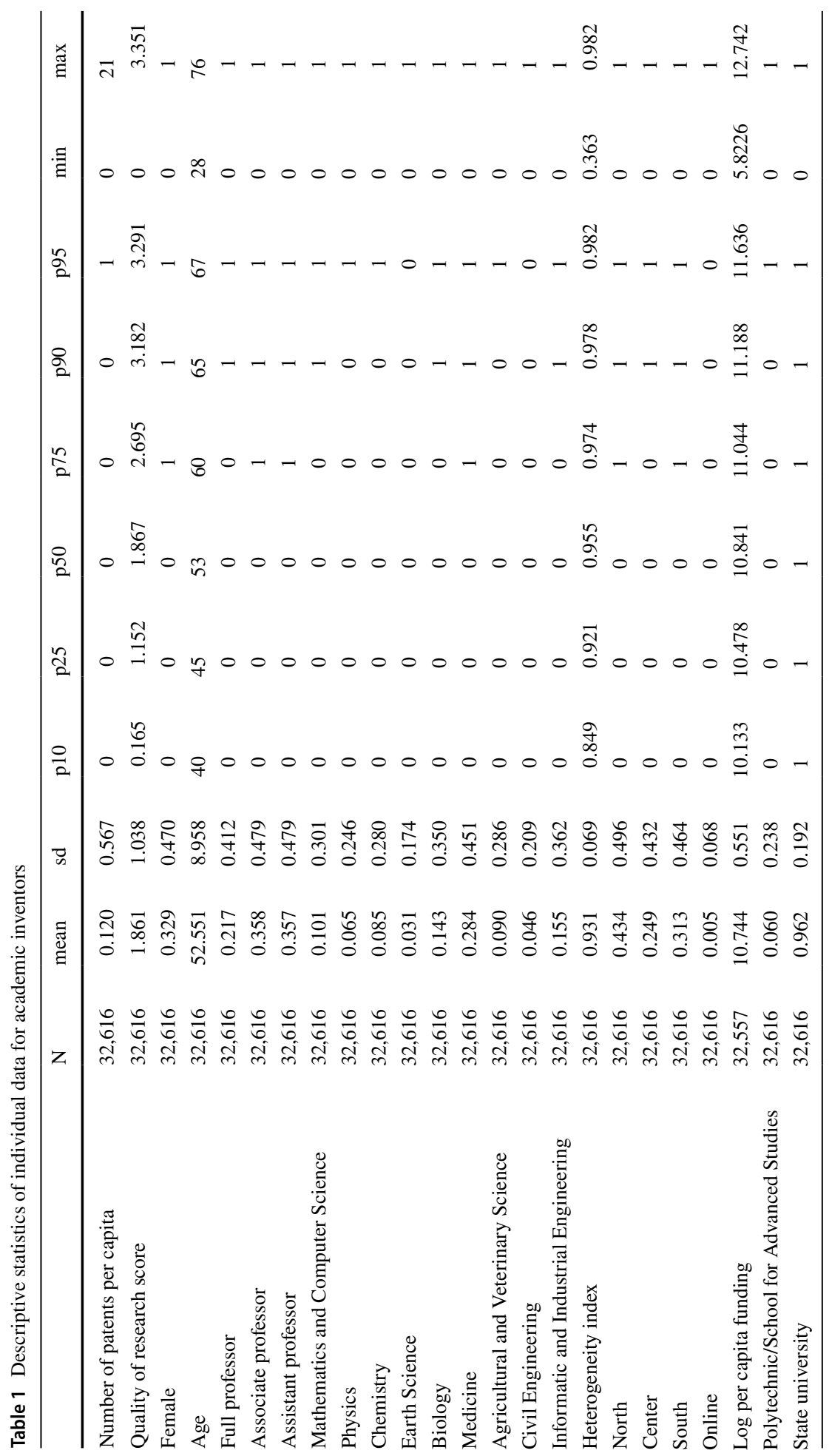




\subsection{Control variables}

Among the control variables, on the basis of the literature, we include the following. Disciplinary variables

- breakdown by discipline (SSD) of inventors (only in the individual level model) Regional variables

- geographic location of the university

\section{Institutional variables}

- state or non-state legal status of the university

- specialist or generalist outline of the university

- graduate-only institutions (Schools for Advanced Studies) and Polytechnics or universities

- presence of a Technology Transfer Office (TTO)

In addition, in the individual model we control for researcher-level variables such as gender, age and academic position (Full professor, Associate professor, Assistant professor).

All data were extracted from the VQR procedure. The definition of specialist or generalist university is attributed by computing the Gini index on the share of research outputs by scientific area.

\section{Main findings}

The following analysis aims to verify the existence of a correlation (and its sign) between the indicators of research quality, research funding and valorization of research. The estimates reported here do not address the problem of endogeneity and reverse causality: due to data limitation (in particular, the cross-sectional nature of data) it is not possible to establish how research and valorization interact and to define a causal link between the variables. More in detail, one can argue that good research quality triggers higher commitment in its valorization while, conversely, a more intense third mission activity creates virtuous circles that produce improvements in the quality of research. For this reason, we aim at finding simple correlations between the two sets of variables.

Table 1 shows descriptive statistics for individual STEM researchers. We have 32,616 observations of academic staff. They work mainly in generalist universities (Heterogeneity index 0.93) and state universities (State university 0.96). These STEM researchers have applied, on average, for 0.12 patents per capita. Remind that here patents are the only indicator used in the analysis at the individual researcher level. In all other cases the unit of analysis is not the individual but the university.

Table 2 shows the correlation matrix between research quality and indicators of research valorization at the university level, reporting in brackets the values of the Student's T statistic. University research quality indicators reported in the table are those defined in the previous paragraph. Indicators of valorization shown in the table are the number of patents and spin-offs per capita; average patent and spin-offs revenues in the VQR period 


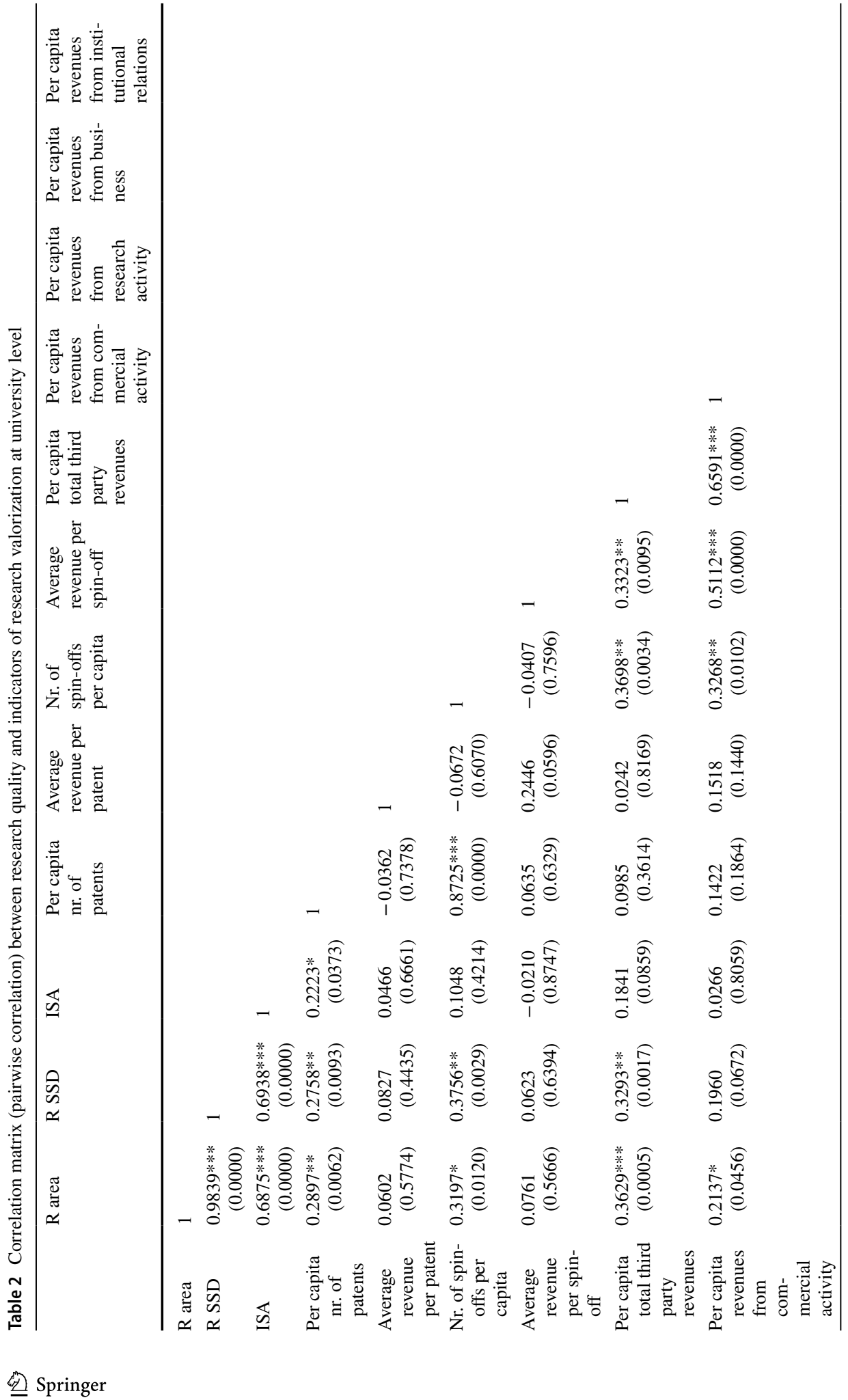




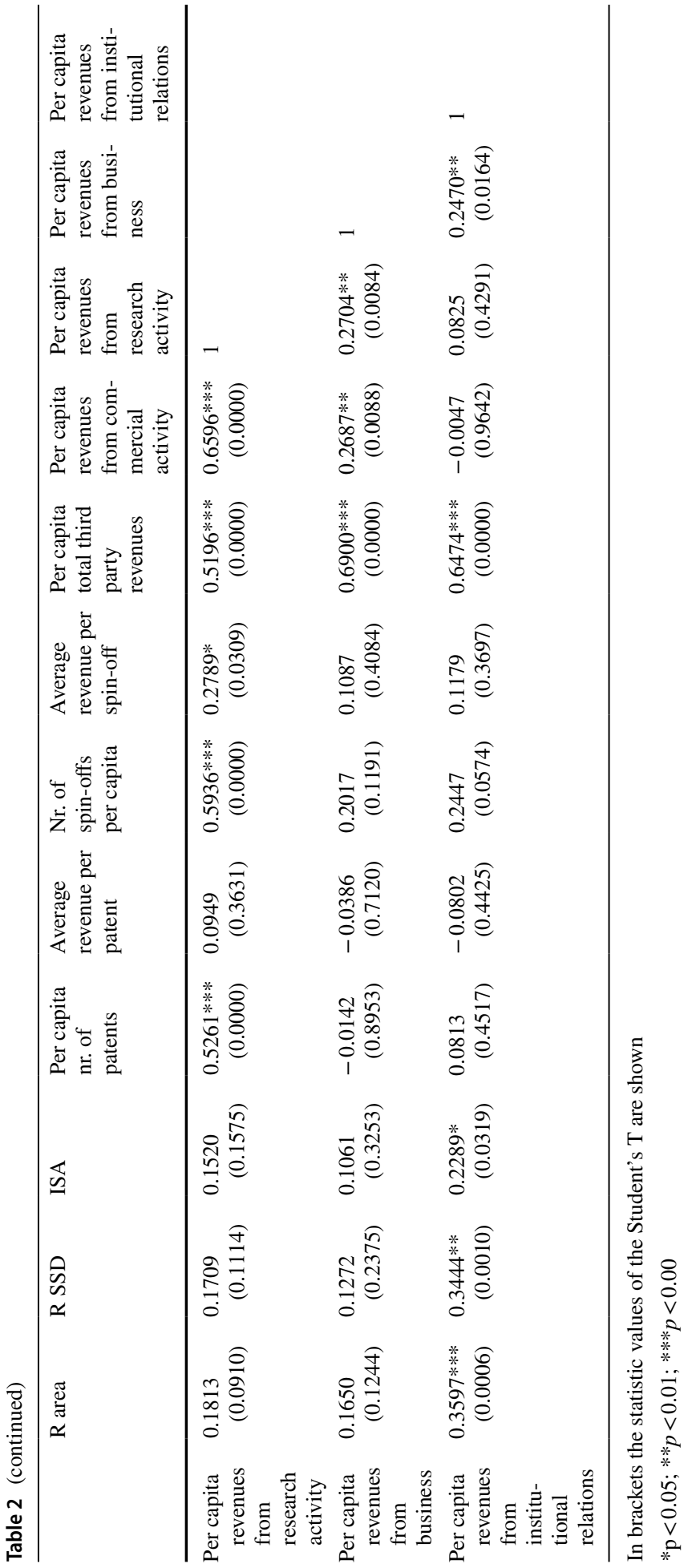



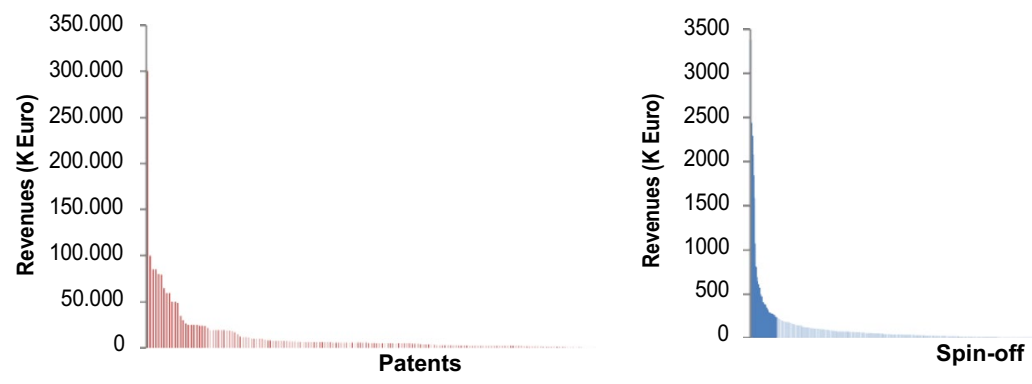

Fig. 1 Distribution of revenues of patents and spin-off in the VQR period 2011-2014. Source: Anvur elaboration on VQR 2011-2014 data, in Blasi et al. (2018).

(2011-2014); total third-party revenues, broken down by relevant item (revenues from research activities carried out on behalf of third parties, revenues from commercial activities, income from business and from institutional relations). All the third-party variables are calculated per capita i.e. by dividing the university totals in the four year of VQR period by the university staff headcount.

Correlation between research quality indicators and the number of per capita patents is positive and significant: in particular, the correlation coefficient varies between 0.22 and 0.29 with a statistical significance of $10 \%$ for normalized research indicators and $5 \%$ for standardized research indicators.

A larger positive correlation of $32 \%$ and $38 \%$ is found between normalized research quality indicators (R Area and R SSD) and the number of per capita spin-off companies with a statistical significance of $5 \%$ in the first case and $10 \%$ in the second case.

Correlations between average patent/spin-off revenues and research quality indicators are positive but not significant. The distribution of patent and spin-off revenues is very skewed and reveals a high concentration (i.e. very few patents/spin-offs produce large revenues), hence it is not surprising that correlation is not statistically significant (Fig. 1).

Correlation between per capita third party revenues and research quality indicators (normalized with respect to Area and SSD) is positive and varies in a range of 33-36\%, statistically significant at $1 \%$ and $5 \%$. With regard to single third party earnings, statistically significant correlations are found between revenues from commercial activities and the $\mathrm{R}$ indicator normalized by Area (at 5\%) and between income from institutional relations and all indicators of research quality.

In order to examine the partial correlations and to test the persistence of the correlation after controlling for observable university characteristics, we build up a regression model at the level of university.

The estimated regression model is the following:

$$
Y_{u}=\alpha+\beta V Q R_{u}+X_{u}^{\prime} \gamma+\varepsilon_{u}
$$

$Y$ represents alternatively the number of patents and spin-off companies per capita and $V Q R_{u}$ represents research quality indicators. We used alternatively the three indicators, that 
Table 3 OLS estimates at university level

\begin{tabular}{llll}
\hline & $(1)$ & $(2)$ & $(3)$ \\
\hline R normalized by area & $0.208^{* * *}(0.0741)$ & $0.0387(0.0998)$ & $0.0416(0.0888)$ \\
South & & $-0.0823^{*}(0.0452)$ & $-0.0889^{* *}(0.0409)$ \\
Polytechnics and School for Advanced & $0.0430(0.0930)$ & \\
$\quad$ Studies & & $-0.0738(0.0624)$ & \\
State university & & $0.273(0.220)$ \\
Heterogeneity index & & $0.000209(0.000383)$ \\
Revenues from commercial activity per & & $0.132^{* * *}(0.0438)$ & $0.134^{* * *}(0.0322)$ \\
$\quad$ capita & & $0.0537(0.0572)$ & \\
Log per capita funding & $-0.0905(0.0737)$ & $-0.216(0.203)$ & $0.0201(0.0833)$ \\
Presence of technology transfer office & 83 & 83 \\
Constant & 88 & 0.295 & 0.265 \\
Observations & 0.084 & &
\end{tabular}

Dependent variable: number of patents per capita

Standard deviation in brackets

${ }^{* * *} p<0.01 ; * * p<0.05 ; * p<0.1$

are highly correlated, defined in the previous paragraph (R Area, $R$ SSD and ISA), while the tables report only the specifications in which we use $R$ normalized by Area. ${ }^{8}$

The vector of the control variables $X^{\prime}$ contains observable university characteristics such as geographical location (binary variable for university's location in Southern Italy); type of institutions (binary variable equal to 1 for Polytechnics and School for Advanced Studies); legal status (binary variable equal to 1 in the case of state university); Gini index of heterogeneity of the disciplinary areas; presence of Technology Transfer Office; average funding from competitive research calls (in logarithm) and revenues from commercial activities carried out on behalf of third parties, both calculated in relation to the university academic staff.

Table 3 contains estimates of the model in which the dependent variable is the number of patents per capita. In the table our variable of interest, i.e. the indicator of the research quality, is positive and significant at $1 \%$. In specification 2 we add university characteristics and find that research quality indicator is no longer statistically significant. University size and type are not statistically significant, while geographical location is statistically significant at $10 \%$, with the Southern universities producing less patents. The presence of a TTO has a positive but not statistically significant coefficient. Funding from competitive calls have a large positive coefficient statistically significant at 1 percentage level. This is an important finding: the higher the ability of universities to procure additional competitive funding, the higher the number of per capita patents. In specification 3 we include only the variables that were significant in model 2 and the research quality variable remains nonstatistically significant.

\footnotetext{
${ }^{8}$ Additional specifications in which we use as control variable alternatively the indicator of research quality normalized by Scientific Sector (SSD) or standardized with respect to the mean and variance of SSD are available on request.
} 
Table 4 OLS estimates at university level

\begin{tabular}{llll}
\hline & $(1)$ & $(2)$ & $(3)$ \\
\hline R normalized by area & $0.169^{* *}(0.0654)$ & $-0.126(0.0778)$ & $-0.0829(0.0661)$ \\
South & & $-0.0166(0.0190)$ & \\
$\begin{array}{l}\text { Polytechnics and School for } \\
\quad \text { Advanced Studies }\end{array}$ & $-0.0380(0.0508)$ & \\
State university & & \\
Heterogeneity index & & $0.278^{* * *}(0.0992)$ & $0.248^{* * *}(0.0838)$ \\
Revenues from commercial activ- & & $0.0959(0.131)$ & \\
$\quad$ ity per capita & $0.00133^{* * *}(0.000411)$ & $0.00116^{* * *}(0.000307)$ \\
Log per capita funding & & $0.000861^{* * *}(0.000192)$ & $0.000641^{* * *}(0.000144)$ \\
Presence of technology transfer & & $-0.0319(0.0424)$ & \\
$\quad$ office & $-0.116^{*}(0.0664)$ & $-0.237(0.146)$ & $-0.183^{*}(0.0979)$ \\
Constant & 61 & 61 & 61 \\
Observations & 0.102 & 0.510 & 0.477 \\
$\mathrm{R}^{2}$ & & & \\
\hline
\end{tabular}

Dependent variable: number of spin-off per capita

Standard deviation in brackets

*** $p<0.01 ; * * p<0.05 ; * p<0.1$

Our estimates show that the relationship between research and patenting is mediated by the effect of funding: universities with good research quality attract more funding and the latter are a decisive variable for the production of patents. More financial resources can facilitate the engagement of universities in patenting activities, especially in STEM areas, which use funding for infrastructure and equipment.

Table 4 shows the results of the model in which the dependent variable is the number of spin-offs per capita. In the first specification, in the absence of control variables, the research quality indicator is positive and significant at 5\%, but with the introduction of the university characteristics (specifications 2 and 3) it is no longer statistically significant. In specifications 2 and 3 state universities coefficient is positive and statistically significant at $1 \%$, hence state universities seem to be more active in terms of firm creation than non-state ones. Third party revenues from commercial activities and funding from competitive calls (in logarithm) are again positively correlated and significant at $1 \%$. Also in the case of spin-off companies, therefore, the funding attractiveness, both from third parties and from competitive calls, positively affect the propensity to create business.

We also have the possibility to analyze patent data at individual level. Table 5 shows the estimates in which the dependent variable is the number of patents produced in the VQR period by individual researchers. The explanatory variables are the research quality indicator, the characteristics of the researcher (gender, age, academic position, disciplinary area) and the institutional characteristics (location, university specialization, legal status, type). In specification 1, in which the only independent variable is the individual score normalized by area without further controls, a positive and statistically significant relationship emerges. In specification 2 , in which personal researcher characteristics are added, the score coefficient continues to be statistically significant at $1 \%$ and positive but decreases by 1 percentage point. All the characteristics considered are statistically significant, in particular, male, young and full professors are more prolific in patenting and, compared to the 


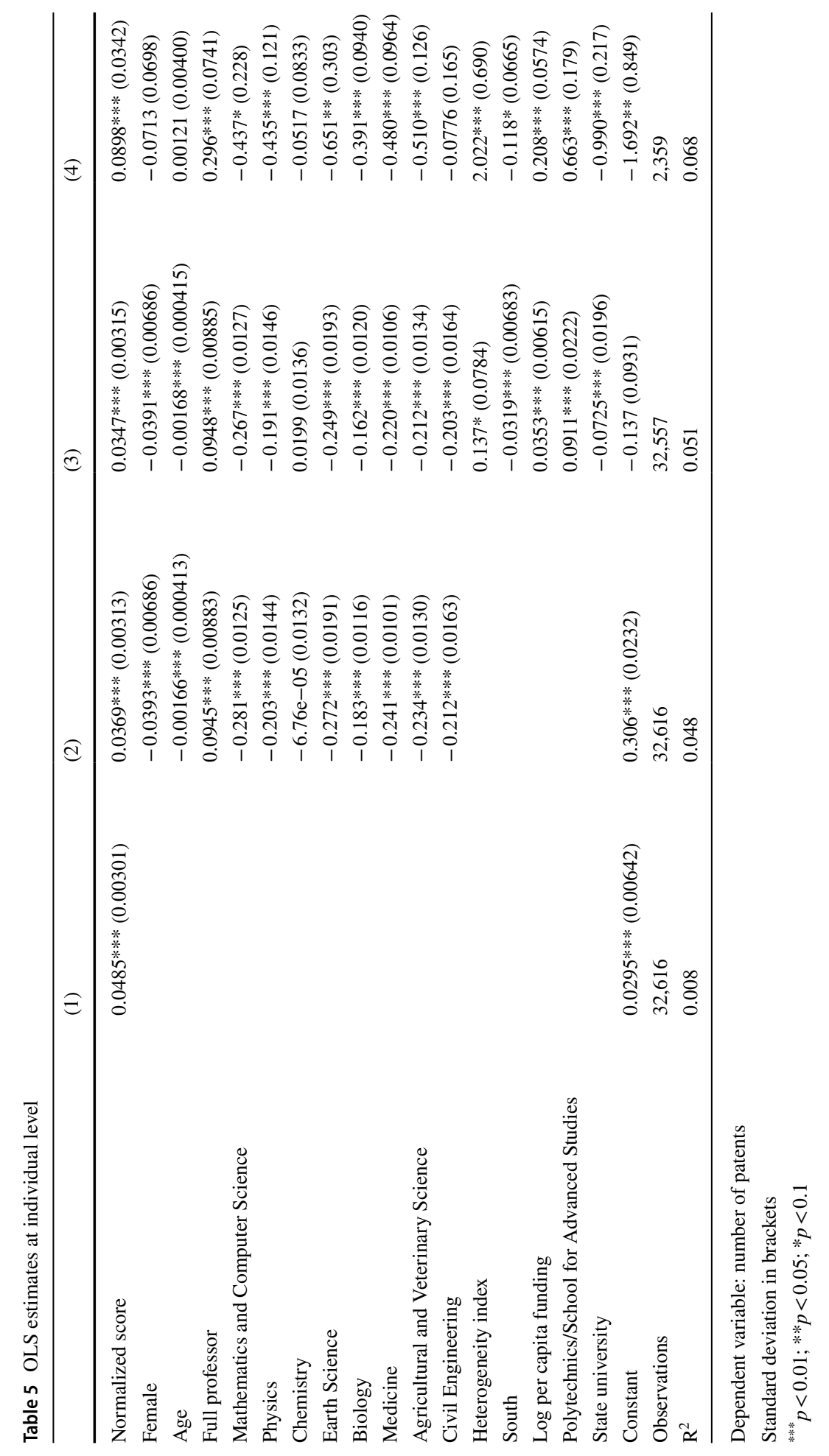


field of Engineering, which is considered the reference group, all the areas have a significant and negative coefficient, except for Chemistry. In specification 3 university variables are included and research quality indicator is still positive and significant at 1 percentage level. In these models the R square is lower than in models at institutional level, given the larger number of determinants of behavior for individual scientists. In future works other estimation techniques might be used in order to address this limitation (e.g. Maximum Likelihood).

Results relative to the individual characteristics are all confirmed and university variables turn out to be statistically significant. In particular the relationship is negative for the state and those located in the South, while there is a positive relationship for Polytechnics and School of Advanced Studies, as well as for funding from competitive calls (in logarithm). Finally, in specification 4, the most complete specification (n.3) was re-estimated excluding researchers not active in patenting. It shows that the positive and statistically significant relationship persists even on the productive subpopulation.

The positive relationship between scientific quality production and patenting activity found in our estimates supports the notion that the most active researchers are also the most prolific in patenting. A similar relationship seems to be confirmed also at the institutional level.

\section{Beyond complementarity: quality of research as source and signal}

In this paper we have analyzed the relationship between research quality and indicators of research valorization, focusing on patents and spin-off companies, and controlling for a set of contextual factors.

In the past two or three decades, the main emphasis of the literature has been on the relation between research quality and valorization, addressing the question whether it has negative or positive sign, and whether a positive sign is sufficient, or necessary but not sufficient, and the like. Our findings support the traditional complementarity view. Estimates confirm a positive correlation between patenting productivity and quality of research and between prolificacy in the creation of spin-off companies and quality of research at university level.

We believe, however, that our findings may contribute to a broader conceptualization, further beyond the classical complementarity versus substitution approach. Quality of research supports research valorization in two distinct ways: as a source of inventive ideas, and as a signal for providers of funding. Good quality of research is a necessary condition for the generation of ideas that have scientific interest, leading to publications, as well as economic value, leading to patents and entrepreneurial initiatives. This is the most studied pathway, confirmed by our findings.

There is also, however, a more indirect, but not less important pathway: good quality research helps to procure more funding not only through competitive calls, but also through third party funding. The relation between quality of research and competitive funding is not surprising, given that most funding schemes include the ex-ante evaluation of the publication profile of team members, or at least of the Principal Investigator. Less obvious is the positive impact on third party funding from various stakeholders and type of activities. Here the quality of research is not a direct source, but a signal of overall quality. Remember that external stakeholders are not directly interested in scientific publications: they are business firms, or non profit funding agencies (e.g. foundations), or institutional actors. 
However, external stakeholders approximate the overall quality of universities by observing the prestige of its publications.

This conceptualization is strongly confirmed by positive coefficients between quality of research and total third party funding at university level (Table 2) and by positive coefficients for almost all funding variables in regression models with patents or spinoff companies as dependent variables (Tables 3, 4, 5), at both individual and university levels.

Other findings of the study are rather confirmatory of the literature: we find a strong disciplinary effect in favor of Engineering and Chemistry, and a regional effect according to which universities in Southern regions produce less valorization outputs. On the contrary, we do not find compelling evidence for structural differences across various forms of universities at aggregate level. At the individual level, on the contrary, it seems that Polytechnics and Schools of Advanced Studies offer the strongest incentives for patenting, while the effect is negative for state universities. Finally, we have no support for the role of TTOs in triggering the valorization outputs.

The latter finding (no important role for TTOs) adds an interesting element to our conceptualization. The activities of TTOs have been justified in the literature as an organizational solution to the issue of substitution between research quality and valorization: if good researchers delegate the activities needed for valorization to dedicated professional teams at university level, then the trade-off would be mitigated.

Our data suggest that this view is too simplified. Engaging into patenting and licensing, or entrepreneurial activities, requires a first-hand personal commitment by researchers, that cannot be delegated. We suggest that highly productive researchers follow another route: they use good quality research to procure additional funds in competitive calls and third party funding, they use additional funds to establish a permanent and effective division of labor by hiring additional staff at the level of team or laboratory, and they use additional staff to engage into valorization and procure new funds. This is a dynamic and virtuous circle, with a positive feedback. This dynamic circle cannot be substituted by any TTO, whatever the level of professionalization of their staff.

Interestingly, this model helps to understand how Italian researchers, although overwhelmed by teaching duties and equipped with modest block research funding, can produce significant valorization output.

\section{Notes}

1. Additional specifications in which we use as control variable alternatively the indicator of research quality normalized by Scientific Sector (SSD) or standardized with respect to the mean and variance of SSD are available on request.

Funding Open access funding provided by Università di Pisa within the CRUI-CARE Agreement.

Open Access This article is licensed under a Creative Commons Attribution 4.0 International License, which permits use, sharing, adaptation, distribution and reproduction in any medium or format, as long as you give appropriate credit to the original author(s) and the source, provide a link to the Creative Commons licence, and indicate if changes were made. The images or other third party material in this article are included in the article's Creative Commons licence, unless indicated otherwise in a credit line to the material. If material is not included in the article's Creative Commons licence and your intended use is not permitted by statutory regulation or exceeds the permitted use, you will need to obtain permission directly from the copyright holder. To view a copy of this licence, visit http://creativecommons.org/licenses/by/4.0/. 


\section{References}

Abramovsky, L., Harrison, R., \& Simpson, H. (2007). University research and the location of business R\&D. The Economic Journal, 117(519), 114-141

Agrawal, A. (2001). University-to-industry knowledge transfer. Literature review and unanswered questions. International Journal of Management Reviews, 3(4), 285-302

Agrawal, A., \& Henderson, R. (2002). Putting patents in context: Exploring knowledge transfer from MIT. Management Science, 48(1), 44-60

Ambos, T. C., Mäkelä, K., Birkinshaw, J., \& d'Este, P. (2008). When does university research get commercialized? Creating ambidexterity in research institutions. Journal of Management Studies, 45(8), 1424-1447

Anfossi, A., Ciolfi, A., Costa, F., Parisi, G., \& Benedetto, S. (2016). Large-scale assessment of research outputs through a weighted combination of bibliometric indicators. Scientometrics, 107(2), 671-683

Barletta, F., Yoguel, G., Pereira, M., \& Rodríguez, S. (2017). Exploring scientific productivity and transfer activities. Evidence from Argentinian ICT research groups. Research Policy, 46(8), 1361-1369

Barra, C., Maietta, O. W., \& Zotti, R. (2019). Academic excellence, local knowledge spillovers and innovation in Europe. Regional Studies, 53(7), 1058-1069

Beaudry, C., \& Allaoui, S. (2012). Impact of public and private research funding on scientific production. The case of nanotechnology . Research Policy, 41(9), 1589-1606

Behrens, T. R., \& Gray, D. O. (2001). Unintended consequences of cooperative research: Impact of industry sponsorship on climate for academic freedom and other graduate student outcome. Research Policy, 30(2), 179-199

Bekkers, R., \& Freitas, I. M. B. (2008). Analysing knowledge transfer channels between universities and industry: To what degree do sectors also matter? Research Policy, 37, 1837-1853

Blasi, B., \& Romagnosi, S. (2012). Social dynamics in scientific practices: Focus on research groups. Sociologia, 46(2), 66-77

Blasi, B., Bonaccorsi, A., Nappi, C. A., \& Romagnosi, S. (2018) Il legame tra qualità e valorizzazione della ricerca. In Rapporto biennale sullo stato del sistema universitario e della ricerca, Chapter III.11.2. Rome, ANVUR.

Blasi, B., Bonaccorsi, A., Nappi, C. A., \& Romagnosi. S. (2019a) The link between research quality and technology transfer in the Italian evaluation of research quality (VQR 2011-2014). In Proceedings of the 17th Conference of the International Society for Scientometrics and Informetrics (ISSI).

Blasi, B., Nappi, C. A., Romagnosi, S. (2019b) People and patents in Italian universities. Characteristics of academic inventors and link with research quality. Proceedings of the 2019 University-Industry Interaction (UII) Conference series. Challenges and solutions for fostering entrepreneurial universities and collaborative innovation.

Blume, S. (1990). Transfer sciences: Their conceptualisation, functions and assessment. Paper presented to the Conference Consequences of the Technology Economy Programme for the Development of Indicators'. OECD, Paris. 2-5 July.

Bolli, T., \& Somogyi, F. (2011). Do competitively acquired finds induce universities to increase productivity? Research Policy, 40(1), 136-147

Bonaccorsi, A. (2016). Addressing the disenchantment. Universities and regional development. Journal of Economic Policy Reform, 20, 293-320

Bonaccorsi, A., \& Cicero, T. (2015). Distributed or concentrated research excellence? Evidence from a large scale research assessment exercise. Journal of the American Society for Information Science and Technology, 67(12), 2976-2992

Bonaccorsi, A., \& Daraio, C. (Eds.). (2007). Universities and strategic knowledge creation. Specialization and performance in Europe. Edward Elgar Publisher.

Bonaccorsi, A., Colombo, M.G., Guerini M., Rossi Lamastra, C. (2013). University specialization and new firm creation across industries. Small Business Economics, 41(4), 837-863

Bonaccorsi, A., Colombo, M.G., Guerini, M., Rossi Lamastra, C. (2014). The impact of local and external university knowledge on the creation of knowledge-intensive firms: Evidence from the Italian case. Small Business Economics, 43(2), 261-287

Bonaccorsi, A. (2020a). Two decades of experience in research assessment in Italy. Scholarly Assessment Reports, 2(1), 16. https://doi.org/10.29024/sar.27

Bonaccorsi, A. (2020b). Two decades of research assessment in Italy. Addressing the criticisms. Scholarly Assessment Reports, 2(1), 17. https://doi.org/10.29024/sar.28

Boyack, K. W., \& Börner, K. (2003). Indicator-assisted evaluation and funding of research. Visualizing the influence of grants on the number and citation counts of research papers. Journal of the American Society for Information Science and Technology, 54(5), 447-461 
Bozeman, B., Gaughan, M., Youtie J., Slade, C.P., Rimes H. (2016) Research collaboration experiences, good and bad. Dispatches from the front lines. Science and Public Policy, 43(2), 226-244.

Bozeman, B., Rhimes, H., \& Youtie, J. (2015). The evolving state-of-the-art in technology transfer research. Revisiting the contingent effectiveness model. Research Policy, 44, 34-49

Breschi, S., Lissoni, F., \& Montobbio, F. (2007). The scientific productivity of academic inventors: New evidence from Italian data. Economics of Innovation and New Technology, 16(2), 71-99

Brown, R. (2016). Mission impossible? Entrepreneurial universities and peripheral regional innovation systems. Industry and Innovation, 23(2), 189-205

Bruno, G. S. F., \& Orsenigo, L. (2003). Variables influencing industrial funding of academic research in Italy: an empirical analysis. International Journal of Technology Management, 26(2-3-4), 277-302

Calcagnini, G., Giombini, G., Liberati, P., \& Travaglini, G. (2016). A matching model of university-industry collaborations. Small Business Economics, 46(1), 31-43

Calderini, M., Franzoni, C., \& Vezzulli, A. (2007). If star scientists do not patent. The effect of productivity, basicness and impact on the decision to patent in the academic world. Research Policy, 36(3), 303-319

Calderini, M., Franzoni, C., \& Vezzulli, A. (2009). The unequal benefits of academic patenting for science and engineering research. IEEE Transactions on Engineering Management, 56(1), 16-30

Callaert, J., Van Looy, B., Verbeek, A., Debackere, K., \& Thijs, B. (2006). Traces of prior art: An analysis of non- patent references found in patent documents. Scientometrics, 69(1), 3-20

Carayol, N. (2003). Objectives agreement and matching in science-industry collaborations. Reassembling the pieces of the puzzle. Research Policy, 37(1), 887-908

Carayol, N. (2007). Academic incentives, research organization and patenting at a large French university. Economics of Innovation and New Technology, 16(2), 71-99

Carayol, N., \& Matt, M. (2004). Does research organization influence academic production? Laboratory level evidence from a large European university. Research Policy, 33(8), 1081-1102

Chang, Y. C., Yang, P. Y., Martin, B. R., Chi, H. R., \& Tsai-lin, T. F. (2016). Entrepreneurial universities and research ambidexterity. A multilevel analysis . Technovation, 54, 7-21

Chapple, W., Lockett, A., Siegel, D., \& Wright, M. (2005). Assessing the relative performance of UK university technology transfer offices. Parametric and Non-Parametric Evidence. Research Policy, 34, 369-384

Colyvas, J., Crow, M., Gelijins, A., Mazzoleni, R., Nelson, R., Rosenberg, N., \& Sampat, B. N. (2002). How do university inventions go into practice? Management Science, 48, 61-72

Crespi, G., D'Este, P., Fontana, R., \& Geuna, A. (2011). The impact of academic patenting on university research and its transfer. Research Policy, 40(1), 55-68

Daraio, C., Bonaccorsi, A., et al. (2011). The European University landscape: A micro characterization based on evidence from the Aquameth project. Research Policy, 40, 148-164

Dasgupta, P., \& David, P. A. (1994). Toward a new economics of science. Research Policy, 23(5), 487-521

Degl'Innocenti, M., Matousek, R., \& Tzeremes, N. (2019). The interconnections of academic research and universities' "third mission". Evidence from the UK. Research Policy. https://doi.org/10.1016/j. respol.2019.05.002

Drucker, J. (2016). Reconsidering the regional economic development impacts of Higher Education Institutions in the United States. Regional Studies, 50(7), 1185-1212

Ebadi, A., \& Schiffauerova, A. (2015) Bibliometric analysis of the impact of funding on scientific development of researchers. In Proceedings of the International Conference on Information System Technology Management (ICISTM), Montreal.

Ebadi, A., \& Schiffauerova, A. (2016). How to boost scientific production? A statistical analysis of research funding and other influencing factors. Scientometrics, 106(3), 1093-1116

Fedderke, J. W., \& Goldschmidt, M. (2015). Does massive funding support of researchers work? Evaluating the impact of the South African research chair funding initiative. Research Policy, 44(2), 467-482

Fini, R., Grimaldi, R., Santoni, S., \& Sobrero, M. (2011). Complements or substitutes? The role of universities and local context in supporting the creation of academic spin-offs. Research Policy, 40(8), 1113-1127

Fini, R., Jourdan, J., \& Perkmann, M. (2018). Social valuations across multiple audiences. The interplay between ability and identity judgments. Academy of Management Journal, 61(6), 2230-2264

Fini, R., \& Toschi, L. (2016). Academic logic and corporate entrepreneurial intentions. A study of the interaction between cognitive and institutional factors in new firms. International Small Business Journal, 34(5), 637-659

Fontana, R., Geuna, A., \& Matt, M. (2006). Factors affecting university-industry R\&D projects: The importance of searching, screening and signalling. Research Policy, 35, 309-323 
Freel, M., Persaud, A., \& Chamberlin, T. (2019). Faculty ideals and universities' third mission. Technological Forecasting and Social Change, 147, 10-21

Freitas, I. M. B., Argou, M. R., \& de Paula, S. E. M. (2013). University-industry collaboration and innovation in emergent and mature industries in new industrialized countries. Research Policy, 42(2013), $443-453$

Friedman, J., \& Silberman, J. (2003). University technology transfer: Do incentives, management, and location matter? Journal of Technology Transfer, 28, 17-30

Fritsch, M., \& Franke, G. (2004). Innovation, regional knowledge spillovers and R\&D cooperation. Research Policy, 33(2), 245-255

Giuri, P., Munari, F., Scandura, A., \& Toschi, L. (2019). The strategic orientation of universities in knowledge transfer activities. Technological Forecasting and Social Change, 138, 261-278

Goldfarb, B. (2008). The effect of government contracting on academic research. Does the source of funding affect scientific output? Research Policy, 37(1), 41-58

Gulbrandsen, M., \& Smeby, J. C. (2005). Industry funding and university professors' research performance. Research Policy, 34(6), 932-950

Hewitt-Dundas, N. (2012). Research intensity and knowledge transfer activity in UK universities. Research Policy, 41, 262-275

Hicks, D., \& Hamilton, K. (1999). Does university-industry collaboration adversely affect university research? Issues in Science \& Technology Online, XV(4), 74-75

Hill, K. (2006) University research and local economic development. Arizona State University's Productivity and Prosperity Project (P3). W.P. Carey School of Business.

Hmieleski, K. M., \& Powell, E. E. (2018). The psychological foundations of university science commercialization. A review of the literature and directions for future research. Academy of Management Perspectives, 32(1), 43-77

Ho, M. H. C., Liu, J. S., \& Kuan, M. C. H. (2016). Torn between academic publications and universityindustry collaboration. Research Evaluation, 25(2), 151-156

Hong, W., \& Su, Y. S. (2013). The effect of institutional proximity in non-local university-industry collaborations: An analysis based on Chinese patent data. Research Policy, 42, 454-464

Hornbostel, S. (2001). Third party funding of German universities. An indicator of research activity? Scientometrics, 50(3), 523-537

Hülsbeck, M., Lehmann, E. E., \& Starnecker, A. (2013). Performance of technology transfer offices in Germany. Journal of Technology Transfer, 38, 199-215

Jacob, B. A., \& Lefgren, L. (2011). The impact of research grant funding on scientific productivity. Journal of Public Economics, 95(9), 1168-1177

Jensen, R., \& Thursby, M. (2001). Proofs and prototypes for sale: The licensing of university inventions. American Economic Review, 91(1), 240-259

Landry, R., Saihi, M., Amara, N., \& Ouimet, M. (2010). Evidence on how academic manage their portfolio of knowledge transfer activities. Research Policy, 39, 1387-1403

Lariviére, V., Macaluso, B., Archambault, É., \& Gingras, Y. (2010). Which scientific élites? On the concentration of research funds, publications and citations. Research Evaluation, 19(1), 45-53

Laudel, G. (2005). Is external research funding a valid indicator for research performance? Research Evaluation, 14(1), 27-34

Laursen, K., \& Salter, A. (2004). Searching high and low: What types of firms use universities as a source of innovation? Research Policy, 33, 1201-1215

Laursen, K., Reichstein, T., \& Salter, A. (2011). Exploring the effect of geographical proximity and university quality on university-industry collaboration in the United Kingdom. Regional Studies, 45(4), 507-523

Laursen, K., \& Salter, A. (2006). Open for innovation: The role of openness in explaining innovation performance among UK manufacturing firms. Strategic Management Journal, 27(2), 131-150

Lawson, C. (2013). Academic patenting: The importance of industry support. Journal of Technology Transfer, 38, 509-535

Lawton-Smith, H., \& Bagchi-Sen, S. (2012). The research university, entrepreneurship and regional development. Research propositions and current evidence. Entrepreneurship and Regional Development, 24(5-6), 383-404

Link, A. N., \& Scott, J. T. (2005). Opening the Ivory Tower's door. An analysis of the determinants of the formation of US university spinoff companies. Research Policy, 34(3), 1106-1112

Link, A. N., \& van Hasselt, M. (2019). On the transfer of technology from universities. The impact of the Bayh-Dole Act of 1980 on the institutionalization of university research. European Economic Review, $119,472-481$ 
Lissoni, F., Llerena, P., McKelvey, M., \& Sanditov, B. (2008). Academic patenting in Europe: New evidence from the KEINS database. Research Evaluation, 17(2), 87-102

Lissoni, F., Pezzoni, M., Potì, B., Romagnosi, S. (2012). University autonomy, IP legislation and academic patenting: Italy, 1996-2007. REPEC Working paper. https://ideas.repec.org/p/hal/journl/hal-00779 750.html

Lockett, A., Wright, M., \& Franklin, S. (2003). Technology transfer and universities' spin-out strategies. Small Business Economics, 20, 185-200

Loi, M., \& Di Guardo, M. C. (2015). The third mission of universities. An investigation of the espoused values. Science and Public Policy, 42(6), 855-870

Maietta, O. W. (2015). Determinants of university-firm R\&D collaboration and its impact on innovation. A perspective from a low-tech industry. Research Policy, 44, 1341-1359

Marx, M., \& Hsu, D. H. (2021). Revisiting the entrepreneurial commercialization of academic science. Evidence from "twin" discoveries. Management Science . https://doi.org/10.1287/mnsc.2021.3966

McAllister, P. R., \& Wagner, D. A. (1981). Relationship between R\&D expenditures and publication output for U.S. colleges and universities. Research in Higher Education, 15(1), 3-30

Meek, W. R., \& Wood, M. S. (2016). Navigating a sea of change. Identity misalignment and adaptation in academic entrepreneurship. Entrepreneurship Theory and Practice, 40(5), 1093-1120

Merton, R. K., \& Merton, R. C. (1968). Social theory and social structure. Simon and Schuster.

Mitroff, I. I. (1974). Norms and counter-norms in a select group of the Apollo moon scientists: A case study of the ambivalence of scientists. American Sociological Review, 39, 579-595

Mongeon, P., Brodeur, C., Beaudry, C., \& Larivière, V. (2016). Concentration of research funding leads to decreasing marginal returns. Research Evaluation, 25(4), 396-404

Mowery, D. C., Nelson, R. R., Sampat, B. N., \& Ziedonis, A. A. (2004). Ivory tower and industrial innovation: University-industry technology before and after the Bayh-Dole Act in the United States. Stanford University Press.

Mulkay, M. J. (1976). Norms and ideology in science. Social Science Information, 15(4-5), 637-656

Munari, F., Sobrero, M., \& Toschi, L. (2016). Financing technology transfer. Assessment of European university-oriented proof-of-concept programs. Technology Analysis and Strategic Management, 29(2), 233-246

Murray, F., \& Stern, S. (2007). Do formal intellectual property rights hinder the free flow of scientific knowledge? An empirical test of the anti-commons hypothesis. Journal of Economic Behavior \& Organization, 63, 648-687

Muscio, A., \& Nardone, G. (2012). The determinants of university-industry collaboration in food science in Italy. Food Policy, 37, 710-718

Nag, S., Yang, H., Buccola, S., \& Ervin, D. (2013). Productivity and financial support in academic bioscience. Applied Economics, 45(19), 2817-3282

Nelson, R. R. (2004). The market economy and the scientific commons. Research Policy, 33, 455-547

O'Shea, R., Allen, T., Chevalier, A., \& Roche, F. (2005). Entrepreneurial orientation, technology transfer and spinoff performance of U.S. universities. Research Policy, 34, 994-1009

OECD. (2013). Science, technology and industry scoreboard. Paris: OECD.

Olmos-Peñuela, C., Castro-Martínez, E., \& D’Este, P. (2014). Knowledge transfer activities in social sciences and humanities. Explaining the interactions of research groups with non-academic agents. Research Policy, 43(4), 696-706

Owen-Smith, J., \& Powell, W. W. (2003). The expanding role of university patenting in the life sciences: Assessing the importance of experience and connectivity. Research Policy, 32(9), 1695-1711

Peer, V., \& Penker, M. (2016). Higher education institutions and regional development. A meta-analysis. International Regional Science Review, 39, 228-253

Perkmann, M., Tartari, V., McKelvey, M., Autio, E., Broström, A., D’Este, P., Fini, R., Geuna, A., Grimaldi, R., Hughes, A., Krabel, S., Kitson, M., Llerena, P., Lissoni, F., Salter, A., \& Sobrero, M. (2013). Academic engagement and commercialisation: A review of the literature on universityindustry relations. Research Policy, 42, 423-442

Powers, J. B., \& McDouglas, P. P. (2005). University start-up formation and technology licensing with firms that go public: A resource-based view of academic entrepreneurship. Journal of Business Venturing, 20, 291-311

Rosenbloom, J. L., Ginther, D. K., Juhl, T., \& Heppert, J. A. (2015). The effects of research and development funding on scientific productivity. Academic Chemistry, 1990-2009. PLOS ONE, 10(9), 1-23

Rosli, A., \& Rossi, F. (2016). Third-mission policy goals and incentives from performance-based funding-Are they aligned? Research Evaluation, 25(4), 427-441

Rothaermel, F. T., Agung, S. D., \& Jian, L. (2007). University entrepreneurship. A taxonomy of the literature. Industrial and Corporate Change, 16(4), 691-791 
Sánchez-Barrioluengo, M. (2004). Articulating the "three-missions" in Spanish universities. Research Policy, 43, 1760-1773

Sánchez-Barrioluengo, M., \& Benneworth, P. (2019). Is the entrepreneurial university also regionally engaged? Analysing the influence of university' structural configuration on third mission performance. Technological Forecasting and Social Change, 141, 206-2018

Schartinger, D., Rammer, C., Fischer, M. M., \& Fröhlich, J. (2002). Knowledge interactions between universities and industry in Austria: Sectoral patterns and determinants. Research Policy, 31, $303-328$

Schoen, A., van Pottelsberghe de la Potterie, B., \& Henkel, J. (2014). Governance typology of universities' technology transfer processes. Journal of Technology Transfer, 39, 435-453

Shane, S. A. (2004). Academic entrepreneurship: University spinoffs and wealth creation. Edward Elgar Publishing.

Siegel, D., Waldman, D., \& Link, A. N. (2003). Assessing the impact of organizational practices on the productivity of university technology transfer offices. An exploratory study. Research Policy, 32(1), 27-48

Siegel, D. S., Veugelers, R., \& Wright, M. (2007). Technology transfer offices and commercialization of university intellectual property. Performance and policy implications. Oxford Review of Economic Policy, 23(4), 640-660

Sine, W. D., Shane, S., \& Di Gregorio, D. (2003). The halo effect and technology licensing: The influence of institutional prestige on the licensing of university inventions. Management Science, 49(4), 478-496

Slaughter, S., \& Leslie, L. L. (1997). Academic capitalism: Politics, policies, and the entrepreneurial university. The Johns Hopkins University Press.

Stiglitz, J. E., \& Wallsten, S. J. (1999). Public-private technology partnerships: Promises and pitfalls. American Behavioral Scientist, 43(1), 52-73

Stokes, D. E. (1997). Pasteur's quadrant. Brookings Institution Press.

Tartari, V., \& Breschi, S. (2012). Set them free: Scientists' evaluations of benefits and costs of university-industry research collaboration. Industrial and Corporate Change, 21(5), 1117-1147

Teixeira, A. A. C., \& Queirós, A. S. S. (2016). Economic growth, human capital and structural change: A dynamic panel data analysis. Research Policy, 45, 1636-1648

Thursby, J. G., Jensen, R., \& Thursby, M. C. (2001). Objectives, characteristics and outcomes of university licensing. A survey of major US universities. The Journal of Technology Transfer, 26(1-2), 59-72

Thursby, J., \& Thursby, M. (2002). Who is selling the ivory tower? Sources of growth in university licensing . Management Science, 48, 90-104

Toole, A., \& Czarnitzki, D. (2010). Commercializing science: Is there a university brain drain from academic entrepreneurship? Management Science, 56(9), 1599-1614

Van Looy, B., Callaert, J., \& Debackere, K. (2006). Publication and patent behaviour of academic researchers: Conflicting, reinforcing or merely co-existing? Research Policy, 35(4), 596-608

Watermeyer, R. (2015). Lost in the "third space". The impact of public engagement in higher education on academic identity, research practice and career progression. European Journal of Higher Education, 5(3), 331-347

Wolszczak-Derlacz, J. (2017). An evaluation and explanation of (in)efficiency in higher education institutions in Europe and the US. With the application of two-stage semiparametric DEA. Research Policy, 46, 1595-1605

Zucker, L., \& Darby, M. (1996). Star scientists and institutional transformation: Patterns of invention and innovation in the formation of the biotechnology industry. Proceedings of the National Academy of Sciences, 93(23), 12709-12716

Publisher's Note Springer Nature remains neutral with regard to jurisdictional claims in published maps and institutional affiliations.

\section{Authors and Affiliations}

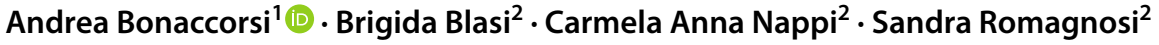

1 DESTEC, University of Pisa, Largo Lucio Lazzarino 2, 56122 Pisa, Italy

2 Italian National Agency for the Evaluation of Universities and Research Institutes, Via Ippolito Nievo, 35, 00153 Rome, Italy 